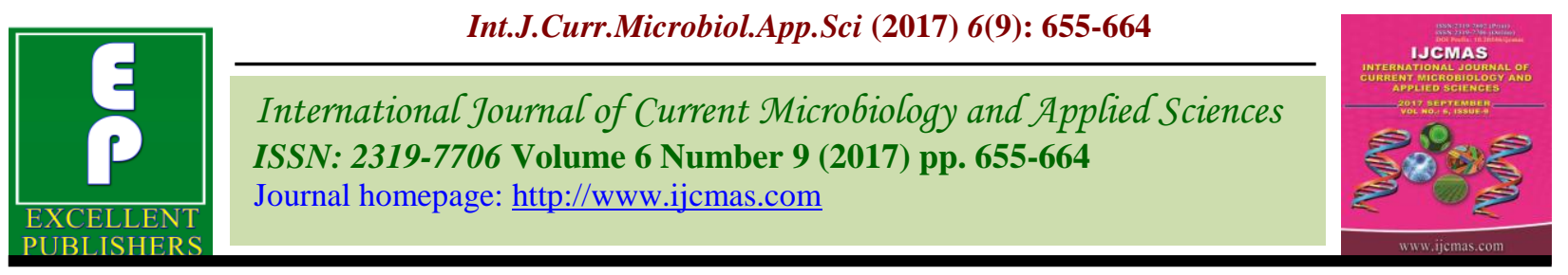

Original Research Article

https://doi.org/10.20546/ijcmas.2017.609.081

\title{
Studies on Changes in Quality Characteristics of Brined Seedling Mango Pieces during Storage
}

\author{
N.S. Thakur, Dharmender Kumar, Abhimanyu Thakur" and Pradeep Kumar
}

Department of Food Science and Technology, Dr YS Parmar University of Horticulture and Forestry, Nauni, Solan - 173230, Himachal Pradesh, India

*Corresponding author

\section{A B S T R A C T}

\section{Keywords}

Seedling mango,

Brine, Storage,

Overall

acceptability,

Pickle.

Article Info

Accepted:

14 July 2017

Available Online:

10 September 2017
Seedling mango (Mangifera indica L.) with wide variations in its quality characteristics has been found in the vast tract of lower hills of HP (Himachal Pradesh). It has got tremendous potential for the production of various traditional products including pickle, since brining is an important interface between harvesting and pickle production, so studies were aimed to see the quality changes of mature green fruit from different locations of HP in brine. Fruits were washed, cut into pieces and stored in 20 per cent brine along with their stones for 4 months at ambient temperature conditions $\left(21-25{ }^{\circ} \mathrm{C}\right)$. Most significant changes in titratable acidity, chlorophyll, ascorbic acid and total phenols were observed along with sensory parameters. Among all the locations, brined mango pieces from Bhoranj location in district Hamirpur were found to be best on the basis of various quality characteristics after storage.

\section{Introduction}

Mango is one of the important fruit crops of India belonging to the genus Mangifera of the family Anacardiaceae. The fruits of Mangifera indica are widely used for table purpose whereas; other edible Mangifera species generally have varying quality fruits which are commonly known as wild mango or seedling mango. Mango is found in wild as well as cultivated form in India, China, Mexico, Pakistan, Indonesia, Nigeria, Thailand, South Central America, Philippines, Brazil, Australia and Egypt (Kumar et al., 2001). It occurs in wild or semi-wild form nearly throughout India in subtropical Himalayas, hills of Western and Eastern
Ghats and the forests of Bihar, Orissa, Assam and Andaman Islands (Singh et al., 2009). In $\mathrm{HP}$, its seedling and cultivated forms are distributed in various parts of districts like Kangra, Hamirpur, Bilaspur, Una, Mandi and Sirmour. The seedling mango is a large evergreen tree about 10 to $45 \mathrm{~m}$ high with a heavy dome shaped crown having a radius of approximately $10 \mathrm{~m}$. Fruit is drupe, variable in form and size, thick or thin skin having leathery green, yellowish or red colour. Its flesh is firm, fibrous, sub acidic and whitish yellow to yellow orange in colour (Anon, 1962). The fruit is a rich source of carbohydrates, vitamin- $\mathrm{C}$ and $\mathrm{A}$, organic 
acids, minerals, anti-oxidants, fibres and proteins (Knight, 1997). Mature green fruits of local varieties or seedling mango trees are mostly used for preparing commercial pickle and traditional products. The fruit is available in bulk quantities during the fruiting season and it is difficult to process all the produce at once to various products. So, brining is one of the alternative approaches to keep the raw material fit until the processing is carried out. Consequently, for the availability of mango throughout the year for the preparation of mango pickle, it is important to store the mature green mango slices in the brine solution in bulk quantity.

\section{Materials and Methods}

\section{Collection of fruit and chemicals}

The fruits of seedling mango at mature green stage were harvested and collected from different locations of HP including Ghumarwin (Bilaspur), Bhoranj (Hamirpur), Gopalpur, Pandoh (Mandi), Sulah, Bhawarna (Kangra), Una Sadar, Amb (Una), Nahan and Ponta Sahib (Sirmour). Selected fruits were washed and cut into pieces manually. The chemicals and other material used during the entire study were procured from local market.

\section{Storage of fruit pieces in brine}

Pieces of mango were dipped in 20 per cent brine before storage and the concentration of brine was maintained 20 per cent by adding sufficient amount of salt till the stabilization of brine concentration. After the stabilization of brine concentration, pieces were packed along with brine in $5 \mathrm{~kg}$ capacity Polyethylene terephthalate (PET) jars and stored under ambient conditions.

\section{Physico-chemical analysis}

The edible content of the samples was observed by removing the stones from the mango fruits. The weighing balance was used to measure edible content of the individual fruit. Moisture, sugars, titratable acidity, ascorbic acid, chlorophyll and starch content of samples were determined according to the standard methods (Ranganna, 1997).

The $\mathrm{pH}$ of fruits was determined by using a digital $\mathrm{pH}$ meter (CRISON Instrument, Ltd, Spain). Total phenols and crude fibre content of fruit samples were determined by standard procedures (Singleton and Rossi, 1965 and Gould, 1978).

\section{Sensory evaluation}

The sensory evaluations of samples were carried out by hedonic rating test (Amerine et al., 1965). The samples were evaluated for sensory qualities based on appearance, texture, taste and overall acceptability. Sensory panel (10 numbers at a time) comprised of faculty members and postgraduate students of department of Food Science and Technology, UHF, Solan (HP) were selected randomly with the care to accommodate different sections and age groups to evaluate the sensory parameters.

\section{Statistical analysis}

The data pertaining to physico-chemical characteristics of fresh seedling mango fruits and brined seedling mango pieces of various locations of HP were analyzed by the Completely Randomized Design (CRD) (Cochran and Cox, 1967). Randomized Block Design (RBD) was used for the analysis of various sensory characteristics (Mahony, 1985).

The parameters for various chemical and sensory characteristics of fruit conducted in these studies were replicated three times and for the physical characteristics were replicated ten times. 


\section{Results and Discussion}

\section{Physico-chemical and sensory characteristics of fruits}

Physico-chemical characteristics of seedling mango samples of different locations are mentioned in table 1. Data indicated that edible content was found between 79.11 and 88.80 per cent. Maximum edible content $(88.80 \%)$ was recorded in Gopalpur and minimum in Amb location $(79.11 \%$ ) which was statistically at par with Ghumarwin and Una Sadar locations. Nearly similar results for edible content of mango fruits have also been reported by Kudachikar et al., (2003) in Rajapuri cultivar, Das et al., (2007) in Mitha and Badamohan cultivars and Singh et al., (2012) in Bombay and Langra cultivars of mango. Maximum moisture content $(89.36 \%)$ of fruit was observed in Nahan and minimum in Sulah location (77.48 \%). Almost, similar results of moisture content of mango fruits have been reported by Anon (1962), Verheij and Coronel (1992) in wild strains and Saroj et al., (2010) in Desi cultivar of mango. Titratable acidity of mango fruits of various locations varied from 2.95 to 4.02 per cent, which was highest $(4.02 \%)$ in Bhoranj and lowest $(2.95 \%)$ in Nahan location which was statistically at par with Amb and Una Sadar. Our findings are similar to the observations reported by Krishanmurthy and Subramanyam (1970); Mann et al., (1974) in Deshehari and Langra cultivars and Singh (2007) in Mangifera andamanica, Mangifera griffithi and Mangifera comptosperma strains of mango. The $\mathrm{pH}$ value of fruits ranged from 2.19 to 2.73 among all the locations. It was recorded maximum (2.73) in Amb and minimum (2.19) in Bhoranj location. The results of $\mathrm{pH}$ of mango fruits are in accordance with the values reported by Mann et al., (1974) in Dashehari and Langra cultivars and Saroj et al., (2010) in Desi cultivar of mango. The chlorophyll content of fruit ranged from 24.74 to $32.23 \mathrm{mg} / 100 \mathrm{~g}$ among the different locations, however, highest $32.23 \mathrm{mg} / 100 \mathrm{~g}$ was found in Bhoranj and lowest $(24.74 \mathrm{mg} / 100 \mathrm{~g})$ in Ponta Sahib location. Similar results of chlorophyll content have been reported by Mann et al., (1974) and Janave and Sharma (2006) in Langra cultivar of mango. The maximum $(8.20 \%)$ starch content of seedling mango fruit was found in Bhoranj closely followed by Sulah and minimum $(7.26 \%)$ in Amb location. Our results are within the range as reported by Moti and Gangwar (1973) in Gaujit and Gulab-e-Khas cultivars and Yadav et al., (1982) in Dashehari and Langra cultivars. The maximum reducing sugars $(2.57 \%)$ of fruit were observed in Bhoranj location and minimum $(2.11 \%)$ in Amb location. The total sugars of fruit were recorded maximum as 3.82 per cent in Bhoranj location which was statistically at par with Sulah, Gopalpur and Una Sadar locations, whereas, minimum (3.29\%) total sugars were observed in Amb location which was statistically at par with Nahan and Bhawarna locations. The results of sugars of seedling mango fruits were within the range as reported by Krishanmurthy and Subramanyam (1970) in Langra cultivar and Moti and Gangwar (1973) in Bombay Green and Bride of Russia cultivars of mango. The ascorbic acid content of fruit ranged from 62.34 to $82.47 \mathrm{mg} / 100 \mathrm{~g}$ among various locations. The highest $(82.47 \mathrm{mg} / 100 \mathrm{~g})$ ascorbic acid was found in Bhoranj and lowest $(62.34 \mathrm{mg} / 100 \mathrm{~g})$ in Ghumarwin location. Nearly, similar results of ascorbic acid have also been recorded by Anon (1962), Moti and Gangwar (1973) in Safeda Pasand and Gurjit cultivars and Mann et al., (1974) in Dashehari and Langra cultivars of mango. Total phenols content of fruits varied from 102.82 to $152.37 \mathrm{mg} / 100 \mathrm{~g}$ among different locations. The maximum (152.37 mg/100 g) total phenols were found in Pandoh and minimum (102.82 $\mathrm{mg} / 100 \mathrm{~g})$ in Amb 
location. The above results are in conformity with the findings of Mann et al., (1974) in Dashehari cultivar. The crude fiber content of fruit varied from 1.06 to 1.88 per cent among different locations. It was recorded highest $(1.88 \%)$ in Pandoh and lowest $(1.06 \%)$ in Gopalpur location, which was statistically at par with Bhoranj, Ghumarwin and Sulah locations. Present findings are almost similar to the values recorded by Yadav et al., (1982) in Ratual and Safeda cultivars of mango. The maximum (3.31) acid-edible content indicator was found in Bhoranj and minimum (2.36) in Amb location.

Data pertaining to sensory characteristics seedling of mango fruits presented in table 2 indicates that the mean score of appearance in seedling mango was observed maximum (8.60) in Bhoranj location, which is statistically at par with Sulah and minimum (7.80) in Ghumarwin and Ponta Sahib locations, which were statistically at par with Amb location. The highest (8.40) texture score of fruit was obtained in Bhoranj location which was statistically at par with Sulah, Gopalpur and Una Sadar locations and lowest (7.25) in Amb which was statistically at par with Pandoh location. Taste score of seedling mango varied from 7.50 to 8.15 . It was obtained maximum (8.15) in Gopalpur location which was statistically at par with Bhoranj location and minimum (7.50) in Bhawarna location. Maximum (7.95) overall acceptability score was obtained in Bhoranj location which was statistically at par with Gopalpur and Sulah locations and minimum (7.15) in Amb location which was statistically at par with Nahan, Pandoh, Una Sadar, Ponta Sahib and Ghumarwin locations. Highest scores of sensory characteristics of seedling mango fruits obtained in Bhoranj location might be due to their attractive dark green colour, shape, texture and more acidic nature. All these sensory quality factors might have lead the judges to award the highest scores to fruits of Bhoranj location as compared to others.

Changes in chemical and sensory characteristics of brined seedling mango pieces during storage

\section{Chemical characteristics}

Data on changes in chemical characteristics of brined mango pieces have been presented in the tables 3 to 5. Data given in table 3 reveal that average titratable acidity of brined mango pieces decreased from 3.30 to 0.96 per cent among all locations. However, it was retained maximum $(2.60 \%)$ in Bhoranj and minimum $(1.86 \%)$ in Amb location at the end of the storage. The decrease in titratable acidity of brined mango pieces might be due to leaching of acid into brine because of its water soluble nature, as well as due to the copolymerization of organic acids with sugars and amino acids (Gupta, 1998). The mean $\mathrm{pH}$ value of brined pieces of mango fruit increased from 2.45 to 3.35 among all locations. It was recorded maximum (3.10) in Amb and minimum (2.78) in Sulah location at the end of storage. Increase in $\mathrm{pH}$ might be due to decrease in titratable acidity in brined mango pieces as $\mathrm{pH}$ has the inverse relationship with acid. The average decrease in chlorophyll content of brined seedling mango pieces was found from 28.39 to 5.17 $\mathrm{mg} / 100 \mathrm{~g}$ among all the locations. However, it was retained highest $(19.87 \mathrm{mg} / 100 \mathrm{~g})$ in Bhoranj and lowest (14.36 mg/100 g) in Ponta Sahib location at the end of storage. Change in the $\mathrm{pH}$ of brine might have lead to the destruction of chlorophyll to pheophytin as a result bright green color of mango pieces turned into olive brown color (Campbell 1937 and Gupte and Francis 1964).

Data pertaining to change in starch, reducing sugars and total sugars of brined mango pieces are presented in table 4 . 
Table.1 Physico-chemical characteristics of seedling mango fruits of various locations

\begin{tabular}{|c|c|c|c|c|c|c|c|c|c|c|c|c|}
\hline \multirow[b]{2}{*}{ Location } & \multicolumn{12}{|c|}{ Characteristics } \\
\hline & $\begin{array}{c}\text { Edible } \\
\text { content } \\
(\%)\end{array}$ & $\begin{array}{c}\text { Moisture } \\
\text { content } \\
(\%)\end{array}$ & $\begin{array}{c}\text { Titratable } \\
\text { acidity } \\
(\%)\end{array}$ & pH & $\begin{array}{c}\text { Chlorophyll } \\
\text { (mg/100 g) }\end{array}$ & $\begin{array}{c}\text { Starch } \\
(\%)\end{array}$ & $\begin{array}{c}\text { Reducing } \\
\text { sugars } \\
(\%)\end{array}$ & $\begin{array}{c}\text { Total } \\
\text { sugars } \\
(\%)\end{array}$ & $\begin{array}{c}\text { Ascorbic } \\
\text { acid } \\
\text { (mg/100 } \\
\text { g) }\end{array}$ & $\begin{array}{c}\text { Total } \\
\text { phenols } \\
\text { (mg/100 } \\
\text { g) }\end{array}$ & $\begin{array}{c}\text { Crude } \\
\text { fibre } \\
(\%)\end{array}$ & $\begin{array}{c}\text { *Acid } \\
\text { edible } \\
\text { content } \\
\text { indicator }\end{array}$ \\
\hline Ghumarwin & 79.51 & 83.26 & 3.16 & 2.56 & 29.50 & 7.62 & 2.41 & 3.60 & 62.34 & 132.55 & 1.13 & 2.51 \\
\hline Bhoranj & 82.27 & 78.58 & 4.02 & 2.19 & 32.23 & 8.20 & 2.57 & 3.82 & 82.47 & 122.51 & 1.12 & 3.31 \\
\hline Gopalpur & 88.80 & 79.24 & 3.24 & 2.28 & 26.61 & 8.10 & 2.37 & 3.70 & 70.73 & 145.88 & 1.06 & 2.88 \\
\hline Pandoh & 85.75 & 82.62 & 3.45 & 2.35 & 26.21 & 7.42 & 2.18 & 3.60 & 74.29 & 152.37 & 1.88 & 2.96 \\
\hline Sulah & 81.90 & 77.48 & 3.79 & 2.22 & 31.49 & 8.12 & 2.44 & 3.77 & 78.36 & 149.54 & 1.16 & 3.10 \\
\hline Bhawarna & 85.47 & 80.85 & 3.19 & 2.36 & 27.58 & 7.38 & 2.12 & 3.35 & 68.29 & 125.44 & 1.28 & 2.73 \\
\hline Una Sadar & 79.36 & 86.65 & 3.05 & 2.62 & 31.33 & 7.86 & 2.35 & 3.65 & 75.48 & 122.81 & 1.45 & 2.41 \\
\hline Amb & 79.11 & 80.21 & 2.98 & 2.73 & 28.69 & 7.26 & 2.11 & 3.29 & 66.88 & 102.82 & 1.37 & 2.36 \\
\hline Nahan & 81.97 & 89.36 & 2.95 & 2.70 & 25.52 & 7.50 & 2.23 & 3.46 & 68.11 & 112.22 & 1.23 & 2.42 \\
\hline Ponta Sahib & 82.21 & 88.13 & 3.12 & 2.45 & 24.74 & 7.78 & 2.31 & 3.54 & 70.11 & 152.29 & 1.37 & 2.56 \\
\hline C.D 0.05 & 2.10 & 0.08 & 0.11 & 0.09 & 0.11 & 0.06 & 0.08 & 0.18 & 0.38 & 0.05 & 0.10 & - \\
\hline
\end{tabular}

*Acid edible content indicator: Titratable acidity x Edible content/100

Table.2 Sensory characteristics scores of seedling mango fruits of various locations

\begin{tabular}{|c|c|c|c|c|c|c|c|c|c|c|c|}
\hline \multirow[b]{2}{*}{ Characteristics } & \multicolumn{9}{|c|}{ Locations } & \multirow[b]{2}{*}{$\begin{array}{l}\text { Ponta } \\
\text { Sahib }\end{array}$} & \multirow[b]{2}{*}{ C.D. 0.05} \\
\hline & Ghumarwin & Bhoranj & Gopalpur & Pandoh & Sulah & Bhawarna & $\begin{array}{c}\text { Una } \\
\text { Sadar }\end{array}$ & Amb & Nahan & & \\
\hline Appearance & 7.80 & 8.60 & 8.20 & 8.10 & 8.45 & 8.58 & 8.50 & 7.85 & 8.10 & 7.80 & 0.15 \\
\hline Texture & 8.00 & 8.40 & 8.20 & 7.35 & 8.25 & 7.90 & 8.20 & 7.25 & 8.15 & 7.70 & 0.20 \\
\hline Taste & 7.80 & 8.05 & 8.15 & 7.60 & 8.00 & 7.50 & 7.55 & 7.75 & 7.60 & 7.65 & 0.17 \\
\hline $\begin{array}{c}\text { Overall } \\
\text { Acceptability }\end{array}$ & 7.45 & 7.95 & 7.70 & 7.20 & 7.80 & 7.50 & 7.30 & 7.15 & 7.16 & 7.31 & 0.30 \\
\hline
\end{tabular}


Table.3 Changes in titratable acidity (\%), $\mathrm{pH}$ and chlorophyll (mg/100 g) in brined seedling mango pieces during storage

\begin{tabular}{|c|c|c|c|c|c|c|c|c|c|}
\hline \multirow{3}{*}{$\begin{array}{l}\text { Location } \\
\text { (T) }\end{array}$} & \multicolumn{3}{|c|}{ Titratable acidity (\%) } & \multicolumn{3}{|c|}{$\mathbf{p H}$} & \multicolumn{3}{|c|}{ Chlorophyll (mg/100 g) } \\
\hline & \multicolumn{2}{|c|}{$\begin{array}{c}\text { Storage } \\
\text { interval (S) } \\
\text { (Months) }\end{array}$} & \multirow[t]{2}{*}{ Mean } & \multicolumn{2}{|c|}{$\begin{array}{c}\text { Storage } \\
\text { interval (S) } \\
\text { (Months) }\end{array}$} & \multirow[t]{2}{*}{ Mean } & \multicolumn{2}{|c|}{$\begin{array}{c}\text { Storage } \\
\text { interval (S) } \\
\text { (Months) }\end{array}$} & \multirow[t]{2}{*}{ Mean } \\
\hline & 0 & 4 & & 0 & 4 & & 0 & 4 & \\
\hline Ghumarwin & 3.16 & 0.94 & 2.05 & 2.56 & 3.40 & 2.98 & 29.50 & 4.55 & 17.03 \\
\hline Bhoranj & 4.02 & 1.18 & 2.60 & 2.19 & 3.43 & 2.81 & 32.23 & 7.50 & 19.87 \\
\hline Gopalpur & 3.24 & 1.09 & 2.17 & 2.28 & 3.30 & 2.79 & 26.61 & 4.45 & 15.53 \\
\hline Pandoh & 3.45 & 1.00 & 2.23 & 2.35 & 3.51 & 2.93 & 26.21 & 5.00 & 15.61 \\
\hline Sulah & 3.79 & 1.10 & 2.45 & 2.22 & 3.33 & 2.78 & 31.49 & 6.21 & 18.85 \\
\hline Bhawarna & 3.19 & 0.95 & 2.07 & 2.36 & 3.43 & 2.90 & 27.58 & 4.70 & 16.14 \\
\hline Una Sadar & 3.05 & 0.96 & 2.01 & 2.62 & 3.15 & 2.89 & 31.33 & 6.10 & 18.72 \\
\hline Amb & 2.98 & 0.73 & 1.86 & 2.73 & 3.46 & 3.10 & 28.69 & 5.12 & 16.91 \\
\hline Nahan & 2.95 & 0.78 & 1.87 & 2.70 & 3.19 & 2.95 & 25.52 & 4.13 & 14.83 \\
\hline Ponta Sahib & 3.12 & 0.88 & 2.00 & 2.45 & 3.31 & 2.88 & 24.74 & 3.98 & 14.36 \\
\hline Mean & 3.30 & 0.96 & 2.13 & 2.45 & 3.35 & 2.90 & 28.39 & 5.17 & 16.78 \\
\hline CD 0.05 & \multicolumn{3}{|c|}{$\begin{array}{c}\mathrm{T}=0.09, \mathrm{~S}=0.04 \\
\mathrm{~T} \times \mathrm{S}=0.13\end{array}$} & \multicolumn{3}{|c|}{$\mathrm{T}=0.06, \mathrm{~S}=0.02$} & \multicolumn{3}{|c|}{$\begin{array}{c}\mathrm{T}=0.15, \mathrm{~S}=0.06 \\
\mathrm{TxS}=0.21\end{array}$} \\
\hline
\end{tabular}

Table.4 Changes in starch (\%), reducing sugars (\%) and total sugars (\%) in brined seedling mango pieces during storage

\begin{tabular}{|c|c|c|c|c|c|c|c|c|c|}
\hline \multirow{3}{*}{$\begin{array}{c}\text { Location } \\
\text { (T) }\end{array}$} & \multicolumn{3}{|c|}{$\operatorname{Starch}(\%)$} & \multicolumn{3}{|c|}{ Reducing sugars (\%) } & \multicolumn{3}{|c|}{ Total sugars (\%) } \\
\hline & \multicolumn{2}{|c|}{$\begin{array}{c}\text { Storage } \\
\text { interval }(\mathbf{S}) \\
\text { (Months) }\end{array}$} & \multirow[t]{2}{*}{ Mean } & \multicolumn{2}{|c|}{$\begin{array}{c}\text { Storage } \\
\text { interval (S) } \\
\text { (Months) }\end{array}$} & \multirow[t]{2}{*}{ Mean } & \multicolumn{2}{|c|}{$\begin{array}{c}\text { Storage } \\
\text { interval (S) } \\
\text { (Months) }\end{array}$} & \multirow[t]{2}{*}{ Mean } \\
\hline & 0 & 4 & & 0 & 4 & & 0 & 4 & \\
\hline Ghumarwin & 7.62 & 4.55 & 6.09 & 2.41 & 0.72 & 1.57 & 3.60 & 1.40 & 2.50 \\
\hline Bhoranj & 8.20 & 5.50 & 6.85 & 2.57 & 0.84 & 1.71 & 3.82 & 1.62 & 2.72 \\
\hline Gopalpur & 8.10 & 5.30 & 6.70 & 2.37 & 0.54 & 1.46 & 3.70 & 1.48 & 2.59 \\
\hline Pandoh & 7.42 & 4.31 & 5.87 & 2.18 & 0.58 & 1.38 & 3.60 & 1.39 & 2.50 \\
\hline Sulah & 8.12 & 5.43 & 6.78 & 2.44 & 0.78 & 1.61 & 3.77 & 1.58 & 2.68 \\
\hline Bhawarna & 7.38 & 4.25 & 5.82 & 2.12 & 0.60 & 1.36 & 3.35 & 1.18 & 2.27 \\
\hline Una Sadar & 7.86 & 4.62 & 6.24 & 2.35 & 0.60 & 1.48 & 3.65 & 1.43 & 2.54 \\
\hline Amb & 7.26 & 4.19 & 5.73 & 2.11 & 0.59 & 1.35 & 3.29 & 1.15 & 2.22 \\
\hline Nahan & 7.50 & 4.40 & 5.95 & 2.23 & 0.60 & 1.42 & 3.46 & 1.25 & 2.36 \\
\hline Ponta Sahib & 7.78 & 4.57 & 6.18 & 2.31 & 0.60 & 1.46 & 3.54 & 1.38 & 2.46 \\
\hline Mean & 7.72 & 4.71 & 6.22 & 2.31 & 0.65 & 1.48 & 3.58 & 1.39 & 2.48 \\
\hline$C D_{0.05}$ & \multicolumn{3}{|c|}{$\mathrm{T}=0.19, \mathrm{~S}=0.08$} & \multicolumn{3}{|c|}{$\mathrm{T}=0.08, \mathrm{~S}=0.03$} & \multicolumn{3}{|c|}{$\mathrm{T}=0.07, \mathrm{~S}=0.15$} \\
\hline
\end{tabular}


Table. 5 Changes in ascorbic acid (mg/100 g), total phenols $(\mathrm{mg} / 100 \mathrm{~g})$ and crude fibre $(\%)$ in brined seedling mango pieces during storage

\begin{tabular}{|c|c|c|c|c|c|c|c|c|c|}
\hline \multirow{3}{*}{$\begin{array}{l}\text { Location } \\
\text { (T) }\end{array}$} & \multicolumn{3}{|c|}{$\begin{array}{l}\text { Ascorbic acid } \\
(\mathrm{mg} / 100 \mathrm{~g})\end{array}$} & \multicolumn{3}{|c|}{$\begin{array}{l}\text { Total phenols } \\
(\mathrm{mg} / \mathbf{1 0 0} \mathrm{g})\end{array}$} & \multicolumn{3}{|c|}{ Crude fibre $(\%)$} \\
\hline & \multicolumn{2}{|c|}{$\begin{array}{c}\text { Storage interval } \\
\text { (S) } \\
\text { (Months) }\end{array}$} & \multirow[t]{2}{*}{ Mean } & \multicolumn{2}{|c|}{$\begin{array}{c}\text { Storage } \\
\text { interval }(S) \\
(\text { Months) }\end{array}$} & \multirow[t]{2}{*}{ Mean } & \multicolumn{2}{|c|}{$\begin{array}{c}\text { Storage interval } \\
\text { (S) } \\
\text { (Months) }\end{array}$} & \multirow[t]{2}{*}{ Mean } \\
\hline & 0 & 4 & & 0 & 4 & & 0 & 4 & \\
\hline Ghumarwin & 62.34 & 32.48 & 47.41 & 132.55 & 101.80 & 117.18 & 1.20 & 1.15 & 1.17 \\
\hline Bhoranj & 82.47 & 51.58 & 67.03 & 122.51 & 95.68 & 109.10 & 1.12 & 1.05 & 1.09 \\
\hline Gopalpur & 70.73 & 42.73 & 56.73 & 145.88 & 105.90 & 125.89 & 1.06 & 0.99 & 1.03 \\
\hline Pandoh & 74.29 & 46.71 & 60.51 & 152.37 & 114.23 & 133.30 & 1.32 & 1.26 & 1.29 \\
\hline Sulah & 78.36 & 49.86 & 64.11 & 149.54 & 109.26 & 129.40 & 1.16 & 1.10 & 1.13 \\
\hline Bhawarna & 68.29 & 34.71 & 51.50 & 125.44 & 99.23 & 112.34 & 1.28 & 1.23 & 1.26 \\
\hline Una Sadar & 75.48 & 46.87 & 61.18 & 122.81 & 96.21 & 109.51 & 1.45 & 1.36 & 1.41 \\
\hline Amb & 66.88 & 36.87 & 51.88 & 102.82 & 88.20 & 95.51 & 1.37 & 1.28 & 1.33 \\
\hline Nahan & 68.11 & 39.24 & 53.68 & 112.22 & 91.32 & 101.77 & 1.23 & 1.18 & 1.21 \\
\hline Ponta Sahib & 70.11 & 41.19 & 55.65 & 152.29 & 113.85 & 133.07 & 1.37 & 1.28 & 1.33 \\
\hline Mean & 71.71 & 42.22 & 56.97 & 131.84 & 101.57 & 116.71 & 1.26 & 1.19 & 1.23 \\
\hline $\mathrm{CD}_{0.05}$ & \multicolumn{3}{|c|}{$\begin{array}{c}\mathrm{T}=0.31, \mathrm{~S}=0.14 \\
\mathrm{~T} \times \mathrm{S}=0.44\end{array}$} & \multicolumn{3}{|c|}{$\begin{array}{c}\mathrm{T}=0.05, \mathrm{~S}=0.02 \\
\mathrm{Tx}=0.08\end{array}$} & \multicolumn{3}{|c|}{$\begin{array}{c}\mathrm{T}=0.09, \mathrm{~S}=\mathrm{NS} \\
\mathrm{TxS}=\mathrm{NS}\end{array}$} \\
\hline
\end{tabular}

Table.6 Changes in appearance, texture, taste and overall acceptability scores in brined seedling mango pieces during storage

\begin{tabular}{|c|c|c|c|c|c|c|c|c|c|c|c|c|}
\hline \multirow{3}{*}{$\begin{array}{c}\text { Location } \\
\text { (T) }\end{array}$} & \multicolumn{3}{|c|}{ Appearance } & \multicolumn{3}{|c|}{ Texture } & \multicolumn{3}{|c|}{ Taste } & \multicolumn{3}{|c|}{$\begin{array}{c}\text { Overall } \\
\text { Acceptability }\end{array}$} \\
\hline & \multicolumn{2}{|c|}{$\begin{array}{c}\text { Storage } \\
\text { interval } \\
(\mathbf{S}) \\
\text { (Months) }\end{array}$} & \multirow[t]{2}{*}{ Mean } & \multicolumn{2}{|c|}{$\begin{array}{c}\text { Storage } \\
\text { interval } \\
(\mathbf{S}) \\
\text { (Months) }\end{array}$} & \multirow[t]{2}{*}{ Mean } & \multicolumn{2}{|c|}{$\begin{array}{c}\text { Storage } \\
\text { interval } \\
(\mathbf{S}) \\
\text { (Months) }\end{array}$} & \multirow[t]{2}{*}{ Mean } & \multicolumn{2}{|c|}{$\begin{array}{c}\text { Storage } \\
\text { interval } \\
(\mathbf{S}) \\
\text { (Months) }\end{array}$} & \multirow[t]{2}{*}{ Mean } \\
\hline & 0 & 4 & & 0 & 4 & & 0 & 4 & & 0 & 4 & \\
\hline Ghumarwin & 7.80 & 7.10 & 7.45 & 8.00 & 7.15 & 7.58 & 7.80 & 7.05 & 7.43 & 7.45 & 7.32 & 7.39 \\
\hline Bhoranj & 8.60 & 7.75 & 8.18 & 8.40 & 7.75 & 8.08 & 8.05 & 7.78 & 7.92 & 7.95 & 7.70 & 7.83 \\
\hline Gopalpur & 8.20 & 7.30 & 7.75 & 8.20 & 7.65 & 7.93 & 8.15 & 7.73 & 7.94 & 7.70 & 7.25 & 7.48 \\
\hline Pandoh & 8.10 & 7.37 & 7.74 & 7.35 & 7.15 & 7.25 & 7.60 & 7.62 & 7.61 & 7.20 & 7.10 & 7.15 \\
\hline Sulah & 8.45 & 7.45 & 7.95 & 8.25 & 7.50 & 7.88 & 8.00 & 7.60 & 7.80 & 7.80 & 7.55 & 7.68 \\
\hline Bhawarna & 8.58 & 7.20 & 7.89 & 7.90 & 7.51 & 7.71 & 7.50 & 7.24 & 7.37 & 7.50 & 7.30 & 7.40 \\
\hline Una Sadar & 8.50 & 7.25 & 7.88 & 8.20 & 7.68 & 7.94 & 7.55 & 7.64 & 7.60 & 7.30 & 7.36 & 7.33 \\
\hline Amb & 7.85 & 7.40 & 7.63 & 7.25 & 7.05 & 7.15 & 7.75 & 7.56 & 7.66 & 7.15 & 7.10 & 7.13 \\
\hline Nahan & 8.10 & 7.41 & 7.76 & 8.15 & 7.25 & 7.70 & 7.60 & 7.59 & 7.60 & 7.16 & 7.52 & 7.34 \\
\hline Ponta Sahib & 7.80 & 7.15 & 7.48 & 7.70 & 7.74 & 7.72 & 7.65 & 7.15 & 7.40 & 7.31 & 7.13 & 7.22 \\
\hline Mean & 8.20 & 7.34 & 7.77 & 7.94 & 7.44 & 7.69 & 7.77 & 7.50 & 7.63 & 7.45 & 7.33 & 7.39 \\
\hline$C D_{0.05}$ & \multicolumn{3}{|c|}{$\begin{array}{c}\mathrm{T}=0.05, \mathrm{~S}=0.02 \\
\mathrm{~T} \times \mathrm{S}=0.08\end{array}$} & \multicolumn{3}{|c|}{$\begin{array}{c}\mathrm{T}=0.06, \mathrm{~S}=0.02 \\
\mathrm{~T} \times \mathrm{S}=0.08\end{array}$} & \multicolumn{3}{|c|}{$\begin{array}{c}\mathrm{T}=0.05, \mathrm{~S}=0.03 \\
\mathrm{~T} \times \mathrm{S}=0.08\end{array}$} & \multicolumn{3}{|c|}{$\begin{array}{c}\mathrm{T}=0.06, \mathrm{~S}=0.03 \\
\mathrm{~T} \times \mathrm{S}=0.08\end{array}$} \\
\hline
\end{tabular}


The average reduction in starch content of brined pieces of mango was found from 7.72 to 4.71 per cent in all locations. Maximum $(6.85 \%)$ starch content was retained in the fruit pieces of Bhoranj and minimum (5.73) in Amb location at the end of storage. Reduction in the starch of brined pieces of mango might be due to hydrolysis of starch into sugars as reported by Lee (1975). The mean decrease in reducing sugars of brined mango pieces observed from 2.31 to 0.65 per cent, however, the maximum reducing sugars $(1.71 \%)$ were retained in Bhoranj and minimum $(1.35 \%)$ in Amb locations at the end of storage. The total sugars of brined pieces of mango decreased from 3.58 to 1.39 per cent during storage. However, maximum $(2.72 \%)$ total sugars were retained in Bhoranj and minimum $(2.22 \%)$ in Amb location at the end of the storage. Decrease in sugars content during storage might be due to their leaching into brine and also due to their involvement in the co-polymerization with organic acids and amino acids.

Data given in table 5 reveal that the average ascorbic acid content of brined mango pieces decreased from 71.71 to $42.22 \mathrm{mg} / 100 \mathrm{~g}$ among all locations. However, the highest $(67.03 \mathrm{mg} / 100 \mathrm{~g})$ ascorbic acid content was retained in Bhoranj and lowest $(47.41 \mathrm{mg} / 100$ g) in Ghumarwin location at the end of storage. Decrease in ascorbic acid might be due to leaching of ascorbic acid into the brine because of its water-soluble nature. Decrease in ascorbic acid in the brined mango pieces might also be due to its degradation into dehydroascorbic acid and furfural during storage. The average total phenol content of brined fruit pieces varied from 131.84 to $101.57 \mathrm{mg} / 100 \mathrm{~g}$ among all the locations and the maximum $(133.30 \mathrm{mg} / 100 \mathrm{~g})$ was retained in Pandoh and minimum $(95.51 \mathrm{mg} / 100 \mathrm{~g})$ in Amb location at the end of storage. Reduction in total phenols of brined mango pieces might be due to their involvement in the formation of polymeric compounds by complexing with proteins and their subsequent precipitation as observed by Abers and Wrolstad (1979) or might also have decreased because of their leaching action into the brine. The mean crude fibre content of brined seedling mango pieces reduced from (1.26 to $1.19 \%$ ) among all locations. It was retained highest $(1.33 \%)$ in Amb and Ponta Sahib and lowest (1.03 \%) in Gopalpur location at end of storage. Retention of maximum titratable acidity, chlorophyll, starch, sugars and ascorbic acid content of brined fruit pieces of Bhoranj location might be due to their higher initial value in fresh form as compared to others.

\section{Sensory characteristics}

Data on changes in sensory characteristics of brined mango pieces during storage presented in table 6 indicates that the mean scores of appearance in brined mango pieces reduced from 8.20 to 7.34. However, it was retained maximum (8.18) in Bhoranj and minimum (7.45) in Ghumarwin location. The average texture score of brined mango pieces reduced from (7.94 to 7.44) among all locations during storage. It was retained maximum (8.08) in Bhoranj and minimum (7.15) in Amb location at the end of storage. The mean taste scores of brined mango pieces reduced from 7.77 to 7.50 among all locations. However, it was retained maximum (7.94) in Gopalpur and minimum (7.37) in Bhawarna location. Mean overall acceptability scores of brined mango pieces reduced from 7.45 to 7.33 during storage. The maximum score (7.83) was retained in Bhoranj and minimum (7.13) in Amb locations at the end of the storage. Decrease in appearance score might be due to degradation of chlorophyll content with the advancement of storage, which leads the judges to award lower scores as compare to fresh seedling mango pieces. The decrease in texture scores might be due to the degradation of tissues due to penetration of salt into brined 
mango pieces. Concentration of higher amount of salt in brined mango pieces and loss of acid from them might have lead the judges to award the lower scores. The decrease in the parameters like colour, texture and taste lead to the judges to award lower score in overall acceptability to the brined mango pieces during storage. Brined mango pieces from all the locations were found to be acceptable at the end of four months of storage for the preparation of mango pickle as per the various sensory and some chemical characteristics.

In Conclusion, during storage period significant changes in various chemical characteristics were observed in brined mango pieces. However, the maximum titratable acidity, chlorophyll, reducing sugars, total sugars, ascorbic acid and total phenols were retained in Bhoranj location, whereas, crude fiber was retained maximum in Una Sadar location. The sensory characteristics scores of fruit pieces like appearance, texture, taste and overall acceptability were also recorded maximum in Bhoranj location. After storage brined mango pieces of all the locations were found to be acceptable for the preparation of mango pickle on the basis of various quality characteristics.

\section{References}

Abers, J.E., and Wrolstad, R.E. 1979. Causative factors of colour determination in strawberry preserves during processing and storage. Journal of Food Science and Technology, 44: 75-81.

Amerine, M.A., Pangborn, R.M., and Roessler E.B. 1965. Principles of sensory evaluation of food. Academic Press, London, pp. 236-268.

Anonymous, 1962. The Wealth of India: Raw material 6th (Ed.). Publication and Information Directorate, CSIR New
Delhi, 484p.

Campwell, H., 1937. Undesirable color changes in frozen peas stored at in sufficient low temperature. Food Research, 2(1): 55-57.

Cochran, W.R., and Cox, C.M. 1967. Experimental Design, John Wiley and Sons, New York, pp. 171-217.

Das, B.K., Ray, D.P., and Acharya, G.C. 2007. Genetic variability in the mango germplasm of Orissa. Indian Journal of Horticulture, 64 (1): 29- 33.

Gould, W.A., 1978. Food quality assurance. The Avi Publishing Company, Westport, Connecticut, pp. 314.

Gupta, G.K., 1998. Standardization of concentrations of additives for development and processing of oil less mango pickle. Indian Food Packer, 4: 15-17.

Gupte, S.M., and Francis, F.J. 1964. Effect of $\mathrm{pH}$ adjustment and high temperature short-time processing on pigment retention in spinach puree. Food Technology, 18: 141-144.

Janave, L., and Sharma, S. 2006. Inhibition of chlorophyll degradation stay green in Langra mango fruits. BARC Newsletter, 270: 80-86.

Knight, R.J., 1997. Important mango cultivars and their description. In: Mango Botany Production and uses. CAB International Wallingford Oxan, UK, pp. 545-565.

Krishnamurthy, S., and Subramanyam, H. 1970. Respiratory, climacteric and chemical changes in tomato fruit. Journal of American society of Horticulture Science, 95(3): 333-337.

Kudachikar, V.B., Kulkarni, M.N., Aradhya, S.M., Prashad, B.A., and Ramana, K.V.R. 2003. Physico-chemical changes during maturity of mango variety Neelam. Journal of Food Science and Technology, 40(3): 285-289.

Kumar, H.N.V., Narayanswamy, P., Theertha, P.D., Mukund, G.K., and Sondur, S.N. 
2001. Estimation of genetic diversity of commercial mango cultivar using RAPD markers. Journal of Horticulture Science and Technology, 76(5): 529533.

Lee, F.A., 1975. Carbohydrates: Basic Food chemistry. Frederick J. Francis, New York, pp. 9-41.

Mahony, M.O., 1985. Sensory evaluation of food: statistical methods and procedures. Marcel Dekker: New York, pp. 168-169.

Mann, S.S., Singh, R.N., and Pandey, R.M. 1974. Maturity studies in Deshehari and Langra cultivars of mango. Haryana Journal of Horticulture Science, 3(3\&4): 97-105.

Moti, and Gangwar, B.N. 1973. Flowering, fruiting, behavior, maturity, yield and quality of some early mango cultivars. Haryana Journal of Horticulture Science, 2(2\&3): 50-60.

Ranganna, S. 1997. Handbook of analysis and quality control for fruit and vegetable products. Tata McGraw Hill: New Delhi. 1112p.

Saroj Kumar, A., Singh, A., and Sharma, M. 2010. Standardization of recipe and method for mango chutney. Haryana Journal of Horticulture Science, 39(3\&4): 247-249.
Singh, B.D., 2007. Comparative study of wild mangoes of Andaman for nutritional composition and rootstock potential. Journal of Plant Genetic Resources, 20(2):137-140.

Singh, N.P., Jerath, N., Singh, G., and Gill, P.P.S. 2012. Physico-chemical characteristics of unexploited mango diversity in sub-mountainous zone of North India. Indian Journal of Plant Genetic Resources, 25(3): 261-269.

Singh, S.K., Sharma, V.K., Kumar, Y., Kumar, S.S., and Sinha, S.K. 2009. Phytochemical and pharmacological investigations on mangiferin. Herba Polonica, 55(1): 126-139.

Singleton, V.L., and Rossi, J.A. 1965. Colorimetry of total phenolics with phosphomolybdic phosphotungstic acid reagent. American Journal of Enology and Viticulture, 16: 144-158.

Verheij, E.V.M., and Coronel, R.E. 1992. Edible fruits and nuts. In: Encyclopedia of Fruits and Nuts Plant Resource of South East Asia. Prosea foundation Boger, Indonesia, pp. 211-216.

Yadav, S.S., Prasad, A., and Abidi, A.B. 1982. Biochemical studies in mango (Mangifera indica) fruits. Progressive Horticulture, 14(1): 51-53.

\section{How to cite this article:}

Thakur, N.S., Dharmender Kumar, Abhimanyu Thakur and Pradeep Kumar. 2017. Studies on Changes in Quality Characteristics of Brined Seedling Mango Pieces during Storage. Int.J.Curr.Microbiol.App.Sci. 6(9): 655-664. doi: https://doi.org/10.20546/ijcmas.2017.609.081 